\title{
NON-SURGICAL RECOVERY OF EQUINE EGGS, AND AN ATTEMPT AT NON-SURGICAL EGG TRANSFER IN HORSES
}

\author{
NORIHIKO OGURI AND YOSHIO TSUTSUMI \\ Department of Animal Science, Faculty of Agriculture, \\ Hokkaido University, Sapporo, Japan
}

(Received 14th September 1971, accepted 17th January 1972)

\begin{abstract}
Summary. Equine ova were successfully recovered non-surgically from the uterine lumen using a three-way system apparatus. The recovery rate was $45 \%$. Ova collected from the uterus were in the blastocyst stage. The transfer of rabbit ova into the uterine lumen of a mare through the cervix hastened the transport of the fertilized equine ovum in the uterine tube. Equine ovum transfers were performed in eleven recipient mares 5 to 7 days after ovulation without success. It was clearly noted that uterine flushing in the dioestrous mare affected the time of the next ovulation.
\end{abstract}

\section{INTRODUCTION}

Non-surgical recovery and transfer of fertilized ova are prerequisites for the practical application of egg transfer in farm animals. The successful transfer of fertilized ova using non-surgical techniques has been reported in cattle by Mutter, Gradon \& Olds (1964), Sugie (1965), Rowson \& Moor (1966) and Rowson, Moor \& Lawson (1969), and in pigs by Polge \& Day (1968). In most of these cases, the fertilized ova were obtained at appropriate stages of development after slaughter or at operation. Because non-surgical collection of fertilized ova from the Fallopian tubes of living animals is practically impossible, it is necessary to wait until the ova have passed into the tip of the uterine horn. Recently, Sugie, Soma, Fukumitsu, Otsuki \& Onuma (1971) reported the successful collection of ova from the uterine lumen in forty-seven out of fiftyseven superovulated cows by a non-surgical method. Apart from this, however, there seems to have been no basic research on the non-surgical collection and transfer of equine fertilized ova.

The aims of the present experiments were, firstly, to attempt non-surgical recovery of fertilized ova from the uterine lumen of mares using the three-way system apparatus of Rowson \& Dowling (1949) and, secondarily, to examine the possibility of egg transfer. It has been possible to examine a non-surgical egg transfer method in the present study, because the cervical canal of the mare is looser and shorter than that of the cow and does not have the spiral conformation of the latter. To avoid artificial and/or environmental factors on egg recovery and transfer, only mares ovulating spontaneously were used. There are no 
reports for superovulation and synchronization of oestrus in mares, though many workers have attempted to induce ovulation by HCG during oestrus (Mirskaja \& Petropavlovskiľ, 1937; Day, 1939, 1940; Hancock, 1948; Nishikawa, 1959; Loy \& Hughes, 1966; Ellicott \& Dziuk, 1970).

\section{MATERIALS AND METHODS}

A total of eighteen adult Hokkaido native pony mares ranging from $2 \frac{1}{2}$ to 13 years of age were used continuously through two breeding seasons of 1969 and 1970. All mares were teased every morning by an active vigorous stallion to detect the onset of oestrus, during which period the ovaries were palpated per rectum once a day. Mares were served by a fertile stallion once a day on alternate days up to the time of ovulation, in eighty out of a total of 142 oestrous periods.

Deposition of rabbit ova in the uteri of mares and recovery of the ova

To test whether ova transferred through the cervix were expelled from the uterine lumen, rabbit ova in $0.3 \mathrm{ml}$ of a mixture of rabbit serum and Ringer's solution including 1000 i.u. penicillin/ml were deposited into the middle

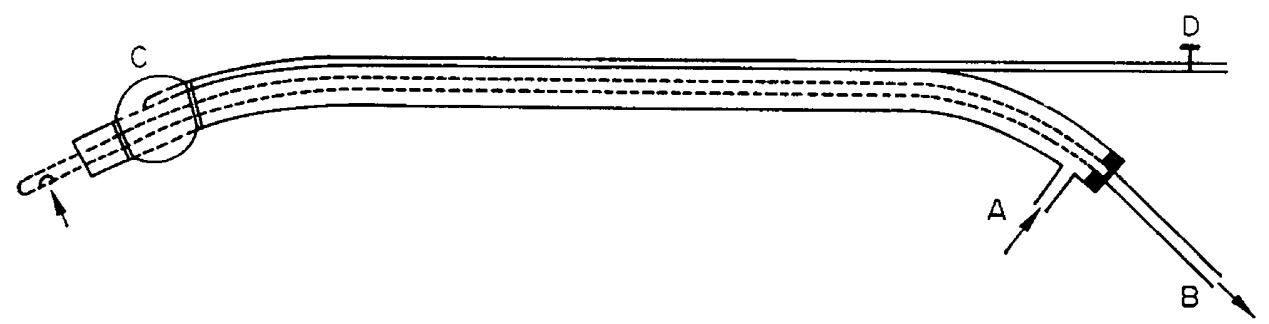

TEXT-FIG. 1. Diagram of the three-way system apparatus used for non-surgical recovery of equine eggs. The external tube (12 mm o.d. and $65 \mathrm{~cm}$ in length) is made of acrylic acid resin, and the larger internal tube of vinyl resin. The tip of the external tube is connected with a fine polyethylene tube by a latex collar. The internal tube is free to move in either direction within the external tube. A, infusion tube (external tube); B, recovery tube (internal tube); $C$, latex collar; $D$, tap on air system; $\uparrow$ : direction of flow.

portion of the uterine horn through the cervix of recipient mares, using a special injector. The injector consisted of an external tube made of acrylic resin $(8 \mathrm{~mm}$ o.d. and $60 \mathrm{~cm}$ in length) and an internal fine polyethylene $(70 \mathrm{~cm}$ in length) tube connected to a $1-\mathrm{ml}$ syringe. Two to ten eggs were deposited 3 and 4 days after ovulation following service in eleven mares and 6 days after ovulation in five mares which had not been served. The eggs were then collected by flushing 5, 24 and $48 \mathrm{hr}$, respectively, after the 3-, 4- and 6-day times of deposition.

Uterine flushings were carried out using a modification of the three-way

\section{EXPLANATION OF PLATE 1}

FIG. 1. Equine ovum obtained from a Graafian follicle $(4.5 \mathrm{~cm}$ in diameter $) . \times 250$.

Fig. 2. Living equine morula 5 days after ovulation. $\times 275$.

FIG. 3. Living early equine blastocyst 6 days after ovulation. $\times 270$.

FIG. 4. Living equine blastocyst 6 days after ovulation. Note the polar body (arrow) and the thread-like structure between the inner cell mass and trophoblast. $\times 265$.

Fig. 5. Living equine blastocyst 7 days after ovulation. $\times 140$.

Fig. 6. Living equine blastocyst 8 days after ovulation. $\times 50$. 

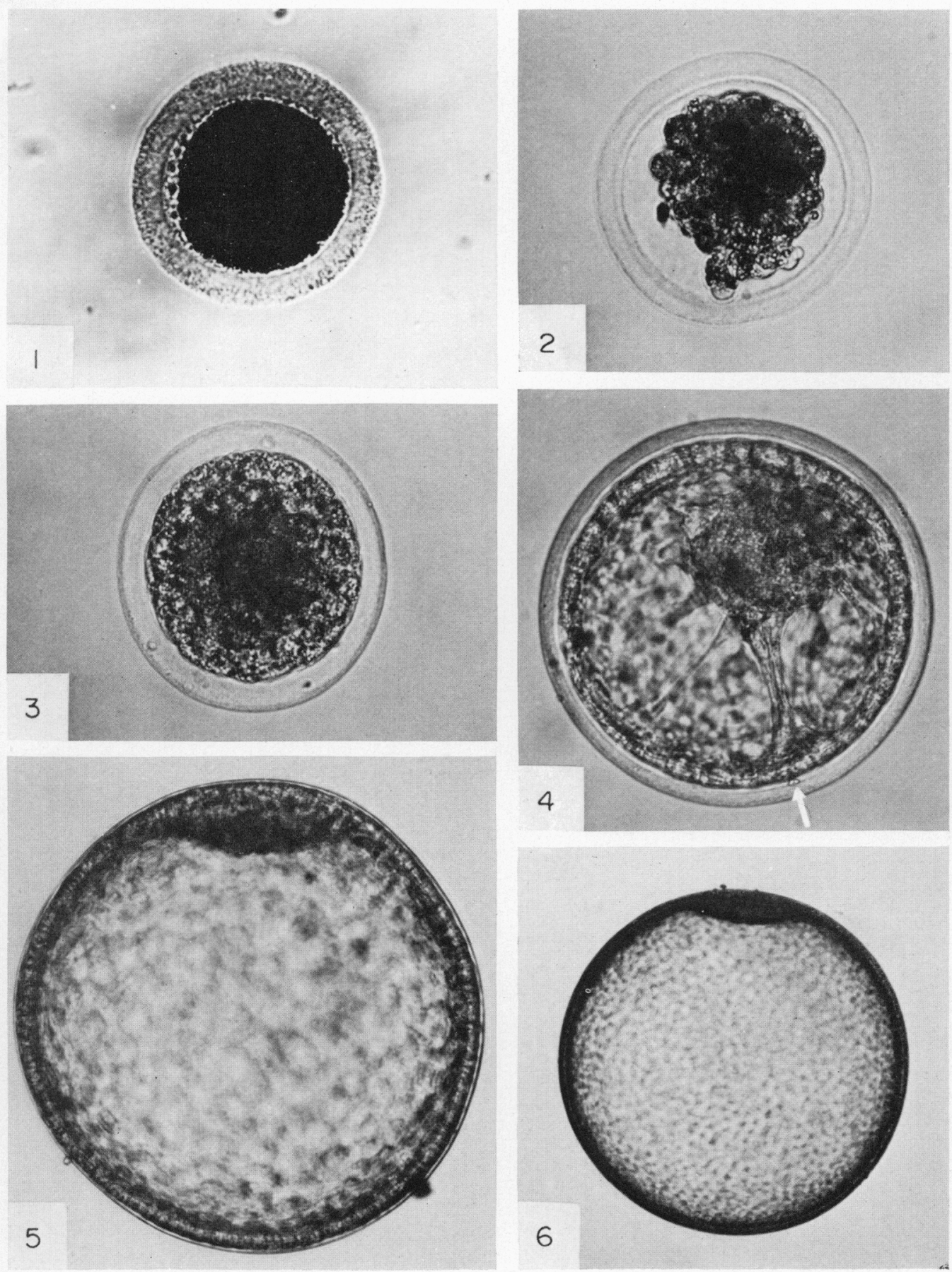

(Facing p. 188) 
system apparatus designed by Rowson \& Dowling (1949) for the extraction of fertilized eggs from the cow (Text-fig. 1).

The apparatus was gently inserted through the cervix into the uterine lumen up to the tip of the horn, the position of the tube being guided by palpation per rectum. After the apparatus was in position in the uterine lumen, the latex collar was inflated with air to block the lumen. Flushing fluid was then infused into the tip of the uterine lumen through the external tube and finally recovered through the internal tube. The uterus was flushed under aseptic conditions, using about $1500 \mathrm{ml}$ physiological saline solution (with $2 \%$ gelatine) or mare serum-saline mixture. The flushings were collected separately into fifteen 100 $\mathrm{ml}$ test tubes and kept at $30^{\circ} \mathrm{C}$ for $20 \mathrm{~min}$. About $3 \mathrm{ml}$ of the fluid at the bottom of each test-tube was then removed to a watch-glass, and the ova were sought under a dissecting microscope.

Non-surgical recovery of fertilized ova from the uteri of mares

Eighty trials of flushing were carried out for fertilized equine ova by the above methods $5,6,7,8,9$ and 10 days after ovulation. The dimensions of twenty-five fertilized equine ova recovered 5 to 8 days after ovulation and of thirty unfertilized ova obtained by puncture of the ovarian follicles of mares at autopsy (Pl. 1, Fig. 1) were measured with the aid of a screw-micrometer eyepiece.

\section{Non-surgical transfer of ova between mares}

Eleven equine eggs (one morula, seven early blastocysts and three blastocysts) were obtained 5 to 7 days after ovulation. On the same day, these eggs were transferred with $0.3 \mathrm{ml}$ of the sterile homologous serum-Ringer's solution mixture with penicillin through the cervix into the uterine horns of eleven recipients which had ovulated spontaneously at the same time as the donors.

\section{RESULTS}

The average percentage volume recovered for a total of eighty-five uterine flushings was $97 \cdot 3 \%$.

\section{Deposition of rabbit ova in the uteri of mares and recovery of the ova}

The results of examinations of the rabbit eggs transferred through the cervix are given in Table 1. Although the recovery ratios of the rabbit ova 5, 24 and $48 \mathrm{hr}$ after transfer decreased with the lapse of time, about $50 \%$ of the ova remained in the equine uterus for more than $48 \mathrm{hr}$. These experiments indicated that non-surgical techniques might be used for the deposition and recovery of equine ova.

Non-surgical recovery of fertilized ova from the uteri of mares

The results of the non-surgical recovery of fertilized equine ova 6, 7, 8, 9 and 10 days after ovulation are shown in Table 2 . Recovered ova were at the early blastocyst and blastocyst stage (Pl. 1, Figs 3 to 6). Although no fertilized equine ovum was recovered in nine uterine flushings on the 5th day after ovulation, some fertilized equine ova were recovered when rabbit ova had been deposited 48 and $24 \mathrm{hr}$ before flushing. For instance, when rabbit ova were transferred 3 days after ovulation and uterine flushings were made $48 \mathrm{hr}$ after the transfer, 
the recovery rate of equine ova was $100 \%$. When depositions of rabbit ova were made on the 4th day after ovulation following flushing $24 \mathrm{hr}$ after deposition, the recovery rate of equine ova decreased to $25 \%$. (Table 3 ).

All ova recovered by flushing on the 5 th day after ovulation were in the morula stage. The blastomeres of these ova were found lying to one side of the zonal

TABLE 1

NON-SURGICAL REGOVERY OF RABBIT OVA TRANSFERRED THROUGH THE GERVIX TO THE UTERI OF REGIPIENT MARES 5 AND 6 DAYS AFTER OVULATION

\begin{tabular}{c|c|c|c|c|c|c}
\hline $\begin{array}{c}\text { Time from } \\
\text { deposition of } \\
\text { rabbit ova to } \\
\text { flushing (hr) }\end{array}$ & $\begin{array}{c}\text { Day from } \\
\text { ovulation } \\
\text { to flushing }\end{array}$ & $\begin{array}{c}\text { No. of } \\
\text { recipient } \\
\text { mares }\end{array}$ & $\begin{array}{c}\text { No. of mares } \\
\text { from which } \\
\text { rabbit ova were } \\
\text { recovered } \\
\text { from uterus }\end{array}$ & $\begin{array}{c}\text { Total no. } \\
\text { of rabbit } \\
\text { ova deposited }\end{array}$ & $\begin{array}{c}\text { Total no. of } \\
\text { rabbit ova } \\
\text { recovered }\end{array}$ & $\begin{array}{c}\text { Recovery } \\
\text { rate } \\
(\%)\end{array}$ \\
\hline 5 & 6 & 5 & 5 & 47 & 33 & $70 \cdot 2$ \\
24 & 5 & 8 & 8 & 60 & 34 & $56 \cdot 7$ \\
48 & 5 & 3 & 3 & 21 & 9 & $42 \cdot 9$ \\
\hline
\end{tabular}

TABLE 2

RECOVERY RATES OF FERTILIZED EQUINE OVA BY NON-SURGIGAL TEGHNIQUES FROM RECIPIENT MARES ON DAYS 6, 7, 8, 9 AND 10 AFTER OVULATION

\begin{tabular}{c|c|c|c}
\hline $\begin{array}{c}\text { Time of flushing } \\
\text { (days after ovulation) }\end{array}$ & No. of flushings & $\begin{array}{c}\text { No. of fertilized } \\
\text { ova recovered }\end{array}$ & \% recovery rate \\
\hline 6 & 36 & 17 & $47 \cdot 2$ \\
7 & 13 & 5 & $38 \cdot 5$ \\
8 & 6 & 2 & $33 \cdot 3$ \\
9 & 3 & 2 & $66 \cdot 6$ \\
10 & 2 & 1 & $50 \cdot 0$ \\
\hline Total & 60 & 27 & $45 \cdot 0$ \\
\hline
\end{tabular}

TABLE 3

EFFECTS OF DEPOSITION OF RABBIT OVA IN THE UTERINE LUMEN OF MARES 48 AND 24 HR BEFORE FLUSHING ON THE RECOVERY OF FERTILIZED EQUINE OVA ON THE 5TH DAY AFTER OVULATION

\begin{tabular}{c|c|c|c}
\hline $\begin{array}{c}\text { Time of deposition } \\
\text { of rabbit ova } \\
\text { (hr before flushing) }\end{array}$ & No. of flushings & Ova recovered & Recovery rate (\%) \\
\hline 48 & 3 & 3 & 100 \\
24 & 8 & 2 & 25 \\
Control & 9 & 0 & 0 \\
\hline
\end{tabular}

cavity, which seemed to be very clear and no granular detritus such as that described by Hamilton \& Day (1945) was found (Pl. 1, Fig. 2). By comparison with rabbit or cow ova, the appearance of the vitellus of the equine ovum was blackish. The means and ranges of the external diameter of ova and the thickness of the zona pellucida of follicles and fertilized ova recovered 5 to 8 days after ovulation are shown in Table 4. 
TABLE 4

MEASUREMENTS OF EQUINE OVA RECOVERED FROM RECIPIENT MARES 5 TO 8 DAYS AFTER OVULATION

\begin{tabular}{c|c|cc|cc}
\hline \multirow{2}{*}{$\begin{array}{c}\text { Age of ovum } \\
\text { (days after ovulation })\end{array}$} & $\begin{array}{c}\text { No. of } \\
\text { ova }\end{array}$ & \multicolumn{2}{|c|}{$\begin{array}{c}\text { Diameter of ova, including } \\
\text { the zona pellucida }(\mu \mathrm{m})\end{array}$} & \multicolumn{2}{|c}{$\begin{array}{c}\text { Thickness of zona pellucida } \\
(\mu \mathrm{m})\end{array}$} \\
\cline { 2 - 6 } & Mean & Range & Mean & Range \\
\hline $\begin{array}{c}\text { Ova obtained } \\
\text { from follicles }\end{array}$ & 30 & 152 & 124 to 168 & 22 & 8 to 33 \\
5 & 3 & 154 & 149 to 161 & 14 & 13 to 16 \\
6 & 17 & 199 & 161 to 289 & 12 & 5 to 22 \\
7 & 3 & 388 & 288 to 485 & 5 & 3 to 7 \\
8 & 2 & 786 & 603 to 968 & 3 & 1 to 5 \\
\hline
\end{tabular}

TABLE 5

RESULTS OBTAINED FOLLOWING NON-SURGICAL TRANSFER

OF EQUINE OVA TO REGIPIENT MARES, WHIGH HAD

OVULATED AT THE SAME TIME AS THE DONORS

\begin{tabular}{c|c|c}
\hline $\begin{array}{c}\text { Time of transfer } \\
\text { (days after ovulation) }\end{array}$ & $\begin{array}{c}\text { Storage time from } \\
\text { recovery to transfer } \\
(\text { min) }\end{array}$ & $\begin{array}{c}\text { Post-operative } \\
\text { cycle length } \\
\text { (days) }\end{array}$ \\
\hline 5 & 105 & 36 \\
$6 *$ & 73 & 14 \\
6 & 123 & 18 \\
6 & 135 & 20 \\
6 & 120 & 20 \\
6 & 120 & 22 \\
6 & 92 & 34 \\
6 & 73 & $>40$ \\
7 & 82 & 20 \\
7 & 47 & 20 \\
7 & 53 & $>80$ \\
\hline
\end{tabular}

* The uterus of this recipient mare was inflated with $\mathrm{CO}_{2}$ immediately after deposition of the fertilized ovum.

TABLE 6

EFFEGTS OF UTERINE FLUSHING FOLLOWING OVULATION ON THE DURATION OF THE OESTROUS GYCLE IN MARES

\begin{tabular}{|c|c|c|}
\hline \multirow[b]{2}{*}{ Treatment } & \multicolumn{2}{|c|}{ Oestrous cycle } \\
\hline & No. of cycles & $\begin{array}{c}\text { Mean duration in days } \pm S . E . \\
\text { (range) }\end{array}$ \\
\hline Normal & 57 & $\begin{array}{l}21 \cdot 12 \pm 0 \cdot 41 \\
(17 \text { to } 26)\end{array}$ \\
\hline $\begin{array}{l}\text { Flushing } 5 \text { to } 8 \text { days after } \\
\text { ovulation }\end{array}$ & 31 & $\begin{array}{l}18 \cdot 48 \pm 0.50 \\
(14 \text { to } 26)\end{array}$ \\
\hline $\begin{array}{l}\text { Deposition of rabbit ova and } \\
\text { flushing } 5 \text { to } 8 \text { days after } \\
\text { ovulation }\end{array}$ & 16 & $\begin{array}{l}17 \cdot 38 \pm 0 \cdot 62 \\
(15 \text { to } 24)\end{array}$ \\
\hline $\begin{array}{l}\text { Flushing } 9 \text { to } 12 \text { days after } \\
\text { ovulation }\end{array}$ & 5 & $\begin{array}{l}26 \cdot 00 \pm 2 \cdot 32 \\
(20 \text { to } 35)\end{array}$ \\
\hline
\end{tabular}


Non-surgical transfer of ova between mares

The results of the non-surgical transfers of equine ova are shown in Table 5. The post-operative cycle length was normal in six of the recipients, but lasted 14,34 and 36 days in three of the recipients, while the other two recipients did not ovulate until 40 and 80 days after transplantation, and subsequently entered the non-breeding season. None of the eleven recipients appeared to be pregnant at any of the subsequent examinations in spite of the fact that no signs of abortion occurred.

Effect of uterine flushing on oestrous cycle length

The effects on oestrous cycle length of uterine flushing on different days after ovulation are summarized in Table 6 . The average length of fifty-seven control oestrous cycles in the Hokkaido native pony was $21 \cdot 12 \pm 0.41$ days (mean \pm S.E.) with a range of 17 to 26 days. The difference (1.10 days) between the mean oestrous cycle lengths of mares flushed 5 to 8 days after ovulation (Groups 5 to 8 ) and of those receiving rabbit ova and flushed 5 to 8 days after ovulation (Groups R.5 to 8 ) was not significant. However, the difference (2.64 days) between the means for Groups 5 to 8 and controls, and the difference (8.62 days) between the means for Groups 5 to 8 and mares flushed 9 to 12 days after ovulation (Groups 9 to 12 ) were significant at a $0.1 \%$ level. The difference (4.88 days) between the mares for the controls and Groups 9 to 12 were significant at a $1 \%$ level.

\section{DISCUSSION}

Imperfect recovery of the rabbit eggs transferred into the equine uterus seems to be attributable to defects in the recovery method and to spontaneous expulsion of the eggs through the cervix. The recovery rate of the rabbit ova from the equine uterus, however, was higher than that described by Hafez \& Sugie (1963) in heifers slaughtered 12 to $48 \mathrm{hr}$ after transfer. The difference between the recovery rate $(70 \%)$ of rabbit ova from the flushings $5 \mathrm{hr}$ after deposition on the 6th day after ovulation and that of equine ova (47\%) from the flushings on the 6 th day after ovulation is probably due to intrinsic differences between the equine and rabbit ova. The significance of such differences remains unexplored.

The recovery of ova from the uterus of mares which had not been induced to superovulate was found to be possible using the three-way system apparatus of Rowson \& Dowling (1949). Compared with that from the cow, the flushings from the mare's uterus contained very little mucus and fragments of epithelial lining; recovery of ova from the mare is, therefore, easier than from the cow. In view of the former findings of Van Niekerk \& Gerneke (1966) that unfertilized ova in the mare remain lodged in the Fallopian tubes and do not reach the uterus, the true mean recovery rate is probably higher than $45 \%$ (Table 2). In an earlier study by Dracy \& Petersen (1950), eggs were recovered from live cows in nine out of thirty-four trials $(26.5 \%)$. Sugie et al. (1971) reported that 257 eggs were recovered from forty-seven out of fifty-seven trials in cows which had been induced to superovulate.

Although equine ova were recovered by uterine flushing on and after 6 days 
(144 to $168 \mathrm{hr}$ ) following ovulation, none were recovered by the same procedure on the 5 th day ( 120 to $144 \mathrm{hr}$ ) after ovulation. The fertilized ovum of the mare may, therefore, appear in the uterine lumen in the early blastocyst stage later than $144 \mathrm{hr}$ after ovulation. Day (1939) recovered an equine ovum from the uterine end of the Fallopian tube about $95 \mathrm{hr}$ after ovulation, following treatment with gonadotrophic hormones. Hamilton \& Day (1945) reported the recovery of an equine ovum at the fifteen-cell stage from the uterine tube $98 \pm 6$ $\mathrm{hr}$ after ovulation. In cattle, however, the egg reaches the uterus $96 \mathrm{hr}$ after oestrus in the eight- to sixteen-cell stage (Hamilton \& Laing, 1946). In a study by El-Banna \& Hafez (1970), all eggs recovered from the uterus consisted of more than eight cells. From these reports and the present data, it appears that the time at which ova arrive in the uterus in the mare is much later than in the cow, and that the cleavage stage of equine ova at arrival is more advanced than in cattle.

Mastroianni \& Rosseau (1965) and Mastroianni, Suzuki, Manabe \& Watson (1967) reported that the presence of an IUD facilitated the rapid transport of fertilized ova through the Fallopian tube in superovulated monkeys. In rats and rabbits, however, Ishihama \& Miyai (1969) stated that the presence of an IUD did not influence the speed of transport or the cleavage of ova in the Fallopian tubes. In the cow, massage of the vulva, massage of the cervix, or a combination of the two, have been reported to induce tetanic uterine contractions which may be due to release of oxytocin (VanDemark \& Hays, 1951). The present results suggest that the rate of transport of fertilized equine ova in the uterine tube is increased by the stimulation which results from deposition of rabbit ova through the cervix.

The inner diameter of the zona pellucida was $135 \mu \mathrm{m}$ in sections of equine ova examined by Hartman (1929), and Hamilton \& Day (1945) noted that the external diameter of the zona of segmented eggs obtained from uterine tubes between 24 and $98 \mathrm{hr}$ after ovulation ranged from 135 to $167 \mu \mathrm{m}$, with a mean of $155 \mu \mathrm{m}$. In the present study, the mean external diameter of the zona pellucida in thirty follicular equine ova was $152 \mu \mathrm{m}$. The size of the morula from the uterus on the 5 th day after ovulation was similar to that of the follicular ova. The size of the blastocyst increased rapidly on and after 6 days, while the thickness of the zona pellucida decreased inversely.

In cattle, Willett, Black, Casida, Stone \& Buckner (1951), Willett, Buckner \& Larson (1953), Avery, Fahning, Pursel \& Graham (1962) and Rowson et al. (1969) have reported successful transplantations of fertilized eggs using surgical methods. Despite many attempts, however, few successes have been reported in the transfer of bovine eggs by non-surgical methods (Mutter et al., 1964; Sugie, 1965; Sugie et al., 1971; Rowson \& Moor, 1966; Rowson et al., 1969). The difficulty in the non-surgical transfer of cattle ova has been ascribed to expulsion of the transferred ova through the cervix, owing to uterine contractions initiated by cervical stimulation (VanDemark \& Hays, 1951; Shah, 1956; Harper, Bennett \& Rowson, 1961; Rowson, Bennett \& Harper, 1964). The cervical canal of the mare, however, is looser and shorter than that of the cow, and more readily allows passage of the instrument of egg transfer. These differences in cervical structure may account for some of the discrepancies in 
cervical stimulation resulting from egg transfer through the cervix. It appears from the present study that the intensity of the contractions leading to the expulsion of ova deposited into the uterine lumen of the mare is weaker than in cattle.

It was postulated by Day (1957) that normal oestrus accompanied by spontaneous ovulation should be induced in the mare by the uterine infusion of about a pint of water at body temperature. Arthur (1970) observed that mares returned to heat on average 3.8 days (range 3 to 7 days) earlier than expected, following infusions performed between the 5th and 9th days of dioestrus; infusions on the 1st to 4th days, or the 12th and 13th days, of dioestrus had no appreciable effect. In the present study, uterine flushing on Days 5 to 8 induced ovulation earlier than would have been expected in normal cycles, while flushings on Days 9 to 12 resulted in later ovulation than normal. It is of interest that uterine flushing during the luteinizing stage shortened the length of the cycle while flushing during the functional stage of corpus luteum deferred the next ovulation.

\section{ACKNOWLEDGMENTS}

The authors wish to express their deep appreciation to Dr E. S. E. Hafez, Wayne State University, U.S.A., for reviewing the manuscript and offering valuable suggestions. They acknowledge with pleasure the unfailing interest and helpful suggestions of Dr Y. Hachinohe, Hokkaido University, and Dr T. Sugie, National Institute of Animal Industry, Chiba, Japan. Thanks are also due to Mr R. Takagi, Hokkaido University Livestock Farm, for his kind advice and technical assistance.

\section{REFERENCES}

ARthUR, G. H. (1970) The induction of oestrus in mares by uterine infusion of saline. Vet. Rec. 86, 584.

Avery, T. L., Fahning, M. L., Pursel, V. G. \& Graham, E. F. (1962) Investigations associated with the transplantation of bovine ova. IV. Transplantation of ova. F. Reprod. Fert. 3, 229.

DAY, F. T. (1939) Ovulation and the descent of the ovum in the Fallopian tube of the mare after treatment with gonadotrophic hormones. . agric. Sci., Camb. 29, 459.

DAY, F. T. (1940) Clinical and experimental observations on reproduction in the mare. F. agric. Sci., Camb. 30, 244.

DAY, F. T. (1957) The veterinary clinician's approach to breeding problems in mares. Vet. Rec. 69, 1258.

Dracy, A. E. \& Petersen, W. E. (1950) Isolation of ova from the living bovine. J. Dairy Sci. 33, 797.

El-Banna, A. A. \& Hafez, E. S. E. (1970) Egg transport in beef cattle. F. Anim. Sci. 30, 430.

EllicotT, A. R. \& Dziuk, P. J. (1970) Control of ovulation and maturation of pony eggs. (Abstract.) F. Anim. Sci. 31, 1036.

HAFEz, E. S. E. \& SuGIE, T. (1963) Reciprocal transfer of cattle and rabbit embryos. F. Anim. Sci. 22, 30.

HAMILTON, W. J. \& DAY, F. T. (1945) Cleavage stages of the ova of the horse, with notes on ovulation. F. Anat. 79, 127.

Hamilton, W. J. \& Laing, J. A. (1946) Development of the egg of the cow up to the stage of blastocyst formation. F. Anat. 80, 194.

HANCOCK, J. L. (1948) Notes on oestrus, ovulation and pregnancy in the mare. Vet. Rec. 60,679.

Harper, M.J. K., BennetT, J. P. \& Rowson, L. E. A. (1961) Movement of the ovum in the reproductive tract. A possible explanation for the failure of non-surgical ovum transfers in the cow. Nature, Lond. 190, 789.

Hartman, G. G. (1929) How large is the mammalian egg? Q. Rev. Biol. 4, 373.

Ishinama, A. \& Mryai, T. (1969) Transport and cleavage of ova in rat and rabbit oviducts with the IUD. Am. F. Obstet. Gynec. 105, 169.

Loy, R. G. \& HuGHEs, J. P. (1966) The effects of human chorionic gonadotrophin on ovulation, length of estrus, and fertility in the mare. Cornell Vet. 56, 41. 
Mastroianni, L., JR \& Rosseau, G. H. (1965) Influence of the intrauterine coil on ovum transport and sperm distribution in the monkey. Am. 7. Obstet. Gynec. 93, 416.

Mastroianni, L., Jr., Suzuki, S., Manabe, Y. \& Watson, F. (1967) Further observations on the influence of the intrauterine device on ovum and sperm distribution in the monkey. Am. F. Obstet. Gynec. 99, 649.

Mirskaja, L. M. \& Petropavlovskir (1937) The reduction of normal duration of heat in the mare by the administration of prolan. Problemy Zhivot. 4, 22. (Anim. Breed. Abstr. 5, 387).

Mutter, L. R., Graden, A. P. \& Olds, D. (1964) Successful non-surgical bovine embryo transfer. A. I. Digest 12, 3. (Anim. Breed. Abstr. 33, 219).

Nishikawa, Y. (1959) Sudies on reproduction in horses. Japan Racing Assn., Tokyo.

Polge, C. \& DAY, B. N. (1968) Pregnancy following non-surgical egg transfer in pigs. Vet. Rec. 82, 712.

Rowson, L. E. A., BennetT, J. P. \& HARPER, M. J. K. (1964) The problem of non-surgical egg transfer to the cow uterus. Vet. Rec. 76, 21.

Rowson, L. E. A. \& Dowling, D. F. (1949) An apparatus for the extraction of fertilized eggs from the living cow. Vet. Rec. 61, 191.

Rowson, L. E. A. \& Moor, R. M. (1966) Non-surgical transfer of cow eggs. F. Reprod. Fert. 11, 311.

Rowson, L. E. A., Moor, R. M. \& LAwson, R. A. S. (1969) Fertility following egg transfer in the cow; effect of methods, medium and synchronization of oestrus. F. Reprod. Fert. 18, 517.

SнAн, M. K. (1956) Reciprocal egg transplantations to study the embryo-uterine relationship in heatinduced failure of pregnancy in rabbits. Nature, Lond. 177, 1134.

Sugie, T. (1965) Successful transfer of a fertilized bovine egg by non-surgical techniques. F. Reprod. Fert. $10,197$.

Sugre, T., Soma, T., Fukumirsu, S., Otsuki, K. \& Onuma, H. (1971) Studies on egg transfer in the cattle; on non-surgical recovery and transfer. (Abstract). Fap. F. zootech. Sci. 42, Suppl. 1, 48.

VanDemark, N. L. \& Hays, R. L. (1951) The effect of oxytocin, adrenalin, breeding techniques and milking on uterine motility in the cow. (Abstract). F. Anim. Sci. 10, 1083.

VAn Niekerk, C. H. \& Gerneke, W. H. (1966) Persistence and parthenogenetic cleavage of tubal ova in the mare. Onderstepoort 7. vet. Res. 33, 195.

Willett, E. L., Black, W. G., Gasida, L. E., Stone, W. H. \& Buckner, P. J. (1951) Successful transplantation of a fertilized bovine ovum. Science, N.Y. 113, 247.

Willett, E. L., BuckNer, P. J. \& LARson, G. L. (1953) Three successful transplantations of fertilized bovine eggs. F. Dairy Sci. 36, 520 . 